ISSN: 2224-0616

Int. J. Agril. Res. Innov. \& Tech. 3 (1): 35-46, J une, 2013 Available online at http:// www.ijarit.webs.com

\title{
MORPHOLOGICAL AND MOLECULAR CHARACTERIZATION OF EGGPLANT LINES FOR RESISTANT TO PHOMOPSIS BLIGHT AND FRUIT ROT
}

\author{
M. Ibrahim Khalil1*, M. Bahadur Meah² and Mirza Mofazzal Islam³
}

Received 18 April 2013, Revised 10 June 2013, Accepted 20 June 2013, Published online 30 June 2013

\begin{abstract}
The $\mathrm{F}_{4}$ lines of eggplant derived from the crosses of Dohazari $\mathrm{G} x$ BAU Begun- 1 and Laffa $\mathrm{Sx}$ BAU Begun-1 were evaluated for resistance to phomopsis blight and fruit rot under confined field conditions. The inoculated plants exhibited differential disease reactions. Among the parents, BAU Begun-1 was resistant whereas Dohazari G and Laffa S were susceptible to Phomopsis vexans. All the phenotypes of $F_{4}$ progenies showed resistant reaction to the disease. Significant differences were observed among the phenotypes in all the yield components. High genotypic and phenotypic coefficient of variation, heritability and per cent genetic advance were estimated for number of fruits per plant, number of secondary branch per plant, fruit length and fruit breadth. Significant positive correlation was observed between yield contributing characters. Random amplified polymorphic DNA technique was used for assessing genetic variation and relationship among parent cultivars and their $\mathrm{F}_{4}$ progenies of eggplant. Amplification with five decamer primers generated $69.0 \%$ polymorphic bands. Comparatively higher genetic distance was observed between Laffa S vs. green globose (Dohazari G x BAU Begun-1). The dendogram constructed from Nei's genetic distance produced two main clusters, the parent cultivars and six $F_{4}$ lines formed cluster 1 and one line in cluster $2 . F_{4}$ lines of the tested phenotypes showed similar disease reaction and divided into same sub cluster. The parent cultivars were different in case of disease reaction and finally divided into two groups, susceptible cultivars Laffa S and Dohazari G belonged to group 1 and the resistant parent BAU Begun-1 formed another group.
\end{abstract}

Keywords: Eggplant, Resistance, Phomopsis, Characterization, RAPD

\footnotetext{
${ }^{1}$ Plant Pathology Division, Bangladesh Institute of Nuclear Agriculture, Mymensingh-2202, Bangladesh

${ }^{2}$ Department of Plant Pathology, Bangladesh Agricultural University, Mymensingh-2202, Bangladesh

${ }^{3}$ Plant Breeding Division, Bangladesh Institute of Nuclear Agriculture, Mymensingh-2202, Bangladesh

*Corresponding author's email: ibrahim_bina@yahoo.com (M. Ibrahim Khalil)
}

\section{Introduction}

Eggplant also known as Brinjal (Solanum melongena L.) is a common fruit vegetable and widely grown in Asia, Africa, and the subtropics, including the southern USA and the Mediterranean region with world production of 42.9 million tons for the year 2009 (FAO, 2010). Asia has the largest eggplant production, which comprises more than $90 \%$ of the world production area and $87 \%$ of the world production (Choudhary and Gaur, 2009). It is the second most important vegetable crop next to potato in Bangladesh in respect of total acreage and production. It is cultivated on about $15 \%$ of total vegetable cultivated land and contributes about $8 \%$ to total vegetable production (BBS, 2011).

Among the diseases of eggplant Phomopsis blight and fruit rot caused by Phomopsis vexans (Sacc. and Syd.) Harter is very devastating and widespread (Chen et al., 2002). Phomopsis blight ranks second only to bacterial wilt in destructiveness of eggplant and varies in severity depending on area, soil type and weather (Meah et al., 2002). Phomopsis vexans is both externally and internally seed borne and remains viable for about 14 months in soil with plant debris and in the seed from infected fruits (Kalda et al., 1977). The pathogen also causes damping off, seedling/ stem blight, collar rot, stem canker and leaf spot. Studies showed that about $21 \%$ of fruit rot and $7 \%$ of seed rot in eggplant is caused by $\mathrm{P}$. vexans and gives final yield losses of 15$50 \%$ (Das, 1998), equivalent to about US \$ 20 million. Farmers have been using expensive pesticides to control the disease, but no satisfactory results could be obtained. Rather, repeated use of pesticides creates environmental pollution and a health hazard. Host plant resistance is the best control method for environmental and financial reasons. BAU Begun-1 is a round shaped variety and only 
resistant variety in Bangladesh cultivated in north-western region (Meah et al., 2007). This variety was crossed with two commercial and popular varieties, Dohazari G and Laffa S. Almost all the $F_{1}, F_{2}$ and $F_{3}$ 's were found to be the resistant to phomopsis blight and fruit rot (Kabir, 2007; Islam, 2006).

Different scientists (Roychowdhury et al., 2011; Sharmin et al., 2010; Islam and Uddin, 2009; Baswana et al., 2002) studied the genetic diversity, heritability and genetic advance in eggplant genotypes. The extensive variability in growth habit, spiny or non-spiny nature, foliage shape/colour, floral structure, fruit shape/size/colour and yields of eggplant were observed to have influence on phomopsis disease reaction (Singh et al., 1999).

The use of molecular markers to track loci and genome regions in crop plants is now routinely applied in many breeding programs. For an effective breeding program, information concerning the extent and nature of genetic diversity or variation within a crop species is essential. Random amplified polymorphic DNA (RAPD) is a widely applied approach for characterization of DNA from plants and other organisms using PCR. The RAPD technique has provided a relatively simple and inexpensive method for analysis of genetic variation in plants, fungi and bacteria (Fukuan et al., 2003; Bidochka et al., 1994). RAPD have been used to construct genetic maps and for the molecular tagging of various agronomic traits in various crop species (Williams et al., 1990).

RAPD technique has been successfully used for the study of genetic variability analysis in different crops including different species of Solanum in Bangladesh and other countries. Laila et al. (2012); Sharmin et al. (2011); Kabir (2007) and Islam (2006) characterized resistant and susceptible cultivars of eggplant along with their interspecific offspring in Bangladesh.

BAU Begun- 1 is yet to be widely cultivated and its popularity is limited to a particular area of the country. So the resistance trait in BAU Begun- 1 is needed to be transferred to some widely cultivated varieties covering larger areas of Bangladesh. So BAU Begun-1 was crossed with two popular commercial varieties of eggplant e.g. Dohazari G and Laffa S. The present research work was undertaken to evaluate the advanced lines of the crosses at $F_{4}$ generation for the inheritance of the resistance trait against Phomopsis vexans and molecular characterization using RAPD markers.

\section{Materials and Methods}

\section{Screening of $F_{4}$ population of eggplant for resistance to Phomopsis blight and fruit rot}

The experiment was conducted in the Field Laboratory of the Department of Plant Pathology, Bangladesh Agricultural University (BAU), Mymensingh, Bangladesh during the winter season of 2006-07.

\section{Source of seed, seedling raising and transplantation}

The seeds of the varieties Dohazari G, Laffa S and BAU Begun-1 and advanced lines $\left(\mathrm{F}_{4}\right.$ generation) of the intervarietal crosses of eggplant, viz. (1) Dohazari G x BAU Begun-1 (2) Laffa S x BAU Begun-1 were collected from IPM Laboratory, Department of Plant Pathology, BAU. Seedlings were raised in the seedbed following proper management.

The seedlings at 28 days age were transplanted in the field. The experiment was laid out in a Randomized Complete Block Design with four replications. The unit plot size was $12.0 \mathrm{~m}$ x 2.0 $\mathrm{m}$ with 2 rows in each plot. Fertilizers and manures were applied at recommended doses (Anonymous, 2005). Application of fertilizers and transplantation were done according to Islam (2006). Weeding, irrigation and other intercultural operations were done whenever necessary.

\section{Inoculation of eggplant by Phomopsis vexans}

A mixer of cultures of five isolates of $\mathrm{P}$. vexans was used for inoculation. The isolates of $P$. vexans were collected from IPM Lab., BAU. The multiplication of $\mathrm{P}$. vexans and preparation of spore suspension were done according to the procedure of Islam (2006). All the plants of $F_{4}$ generations and parents were inoculated at the flowering and fruiting stage. Spore suspension (5 x $10^{6}$ spores $\mathrm{ml}^{-1}$ ) was sprayed @ $70 \mathrm{ml}$ per plant (Islam, 2006). The spraying was done at afternoon and inoculated plants were covered with transparent polythene bag for 48 hours for making favourable condition of infection.

\section{Assessment of Phomopsis blight and fruit rot}

After inoculation, symptoms on leaves, flowers and fruits were observed at seven-day interval up to 21 days. Data on leaf infection (\%), per cent leaf area diseased (LAD), flower infection (\%), fruit infection (\%) and per cent fruit area diseased (FAD) were recorded. The disease severity was recorded according to the standard rating scale (1-5) (Islam et al., 1990). The percent disease index (PDI) was calculated according to the formula of Singh (1984). 


\section{Harvesting and data recording}

The characters responsible for yield of eggplant were studied and data were recorded from the parents and $F_{4}$ populations from all the plants. Plant height, number of primary branches per plant, number of secondary branches per plant, number of fruits per plant, fruit length, fruit breadth and individual fruit weight were recorded in the field. The mature fruits were harvested at the edible stage at an interval of seven days. Five fruits per variety/genotype were allowed to ripe and seeds were collected from them for growing plants in the next year.

\section{Data analysis}

Data were analyzed to find out the statistical significance. Analysis of variances followed by Duncan's Multiple Range Test (DMRT) was performed to test the differences between the genotypes with the computer based software MSTATC.

Besides, different components of genotypic and phenotypic variance, heritability, genetic advance and correlation were also estimated. Genotypic and phenotypic variances and heritability in broad sense were estimated according to formula given by Johnson et al. (1955), genotypic and phenotypic coefficients of variation by the formula of Burton (1952). The expected genetic advance (GA) for different characters under investigation was estimated according to the formula used by J ohnson et al. (1955) and Allard (1960). Genetic advance in percentage of mean was calculated by the formula used by Comstock and Robinson (1952).

Using the formula of Singh and Chaudhary (1985), genetic and phenotypic covariances were calculated. Genotypic and phenotypic correlation coefficients between different characters in all possible combinations were calculated with the formula given by Miller et al. (1958).

\section{Molecular characterization of $F_{4}$ population of eggplants through RAPD markers}

\section{Plant materials}

Three parents (BAU Begun-1, Laffa $\mathrm{S}$ and Dohazari G) and seven $F_{4}$ lines obtained from their crosses (Dohazari G x BAU Begun-1 and Laffa S x BAU Begun-1) were used for the molecular characterization through random amplified polymorphic DNA (RAPD) technique. The experiment was carried out in the Biotechnology Laboratory of the Bangladesh Institute of Nuclear Agriculture, Mymensingh, Bangladesh.

\section{Genomic DNA Extraction}

Fresh leaf samples collected from 14-day old seedling were used for the study. Modified CTAB mini-prep method was followed to extract DNA from leaf samples (Kabir, 2007).

Approximately $25 \mathrm{mg}$ of leaf tissues were cut into small pieces and ground with a pre cooled mortar and pestle. The ground powder was mixed with $670 \mu \mathrm{l}$ extraction buffer $(50 \mathrm{mM}$ Tris-HCl, $25 \mathrm{mM}$ EDTA, $5 \mathrm{M} \mathrm{NaCl}$ ) and $40 \mu \mathrm{l}$ SDS (20\%). The mixture was then transferred in a $2.0 \mathrm{ml}$ micro centrifuge tube (Eppendorf, Germany) and mixed thoroughly. The samples were vortexes for 20 seconds and incubated at $65^{\circ} \mathrm{C}$ for 10 minutes in water bath (DSB-1000). The digested mixture was removed from water bath and $100 \mu \mathrm{l} 5 \mathrm{M} \mathrm{NaCl}$ was added and mixed by inversion. One hundred micro liters CTAB (BioBasic, Canada) was added and mixed by vortexing. The tubes were again incubated in water bath at same temperature for 10 minutes. Nine hundred micro liter chloroform (chloroform: isoamyl alcohol $=24: 1, \mathrm{v} / \mathrm{v}$ ) was added to the mixture after cooling in room temperature and mixed gently to separate the DNA from protein. The extracts were centrifuged for 10 minutes at $14000 \mathrm{rpm}$ with a micro centrifuge (SIGMA 1-14) to allow precipitation of the cell debris. The supernatant was carefully transferred to a new $1.5 \mathrm{ml}$ micro centrifuge tubes without disturbing the lower portion. Equal volume of ice cooled Isopropanol was added to the tubes, mixed gently by trapping with finger, and centrifuged for 10 minutes at $14000 \mathrm{rpm}$. The supernatant was decanted and pellets were air dried for few minutes, washed with $70 \%$ ethanol $(200 \mu \mathrm{l})$, and then centrifuged for 5 minutes at $14000 \mathrm{rpm}$. Then the liquid was completely removed without disturbing the DNA pellet when air dried for 2 hours at room temperature. Finally, the pellets were suspended in $30.0 \mu \mathrm{l}$ of TE buffer (10 mM Tris-HCl, $1 \mathrm{mM}$ EDTA) and stored at $-20^{\circ} \mathrm{C}$.

The quality of the DNA was verified by electrophoreses on a $0.8 \%$ agarose gel in TBE (Tris-boric acid-EDTA) buffer. The concentration of DNA samples was determined using a UV Spectrophotometer at $260 \mathrm{~nm}$.

\section{PCR amplification and Electrophoresis}

RAPD reactions were maintained following the process of Williams et al. (1990) with some modifications. Thirty arbitrary decamer primers (Bengalore Genei, India) against DNA from parental cultivars were screened and five primers producing good scoreable and reproducible bands were selected for subsequent RAPD analysis of eggplant cultivars and phenotypes (Table 5). 
PCR reactions were performed on each DNA sample in a 10.0 $\mu \mathrm{l}$ reaction mixture containing 1X PCR buffer (10 mM Tris $\mathrm{HCl}, \mathrm{pH}$ 8.5; $50 \mathrm{mM}$ $\mathrm{KCl}$ and $15 \mathrm{mM} \mathrm{MgCl}_{2}$ ), $10 \mathrm{mM}$ each dNTPs (Bengalore Genei, India), 5 pmols primer, $2 \mathrm{U}$ of Taq DNA polymerase (Bengalore Genei), $100 \mathrm{ng}$ of genomic DNA and rest amount of sterile deionized water. DNA amplification was carried out in a DNA thermocycler (Biometra, Germany) at the thermal profile: initial denaturation for 3 min at $94^{\circ} \mathrm{C}$ followed by 41 cycles of $1 \mathrm{~min}$ denaturation at $94^{\circ} \mathrm{C}, 1 \mathrm{~min}$ annealing at $35^{\circ} \mathrm{C}$ and extension at $72^{\circ} \mathrm{C}$ for $2 \mathrm{~min}$. A final extension step at $72^{\circ} \mathrm{C}$ for $10 \mathrm{~min}$ was allowed for complete extension of all amplified fragments (Kabir, 2007). Amplified fragments were separated on a $1.5 \%$ agarose (Invitrogen, Canada) gel in $1 \mathrm{X} \mathrm{TBE}$ buffer along with 20 bp DNA weight marker (Bengalore Genei, India) for 2 hours at 100V. Gel was stained with Ethidium bromide solution (0.1 $\mu \mathrm{g} \mathrm{ml}^{-1}$ ) for $20 \mathrm{~min}$. Finally fragments were visualized under UV-transilluminator and photographed by Gel Documentation System (Biometra, Germany).

\section{Scoring and Data analysis}

The amplified bands were visually scored as present (1) and absent (0) separately for each individual and each primer. The scores obtained were pooled to create a single data matrix. This was used to estimate polymorphic loci, Nei (1972) genetic diversity, genetic distance and a UPGMA (Unweighted Pair Group Method with Arithmetic Means) dendrogram using a computer program, POPGENE (Version 1.31) (Yeh et al., 1999).

\section{Results and Discussion}

\section{Screening of $F_{4}$ lines of eggplant for resistance to Phomopsis blight and fruit rot}

$\mathrm{F}_{4}$ advanced lines of eggplants and respective parents showed different percentage of leaf infection and severity (leaf area diseased) after inoculation (Table 1). Among the seven $\mathrm{F}_{4}$ lines and their respective parents, the highest (32.47\%) leaf infection was found in cultivar Dohazari G followed by Laffa S (30.57\%). The eggplant cultivar BAU Begun-1 did not produce any infection on leaf. In contrast, the $\mathrm{F}_{4}$ lines (Dohazari G x BAU Begun-1) and (Laffa S x BAU Begun-1) showed leaf infection of 2.87 to $3.12 \%$ and 2.83 to $3.16 \%$, respectively. Similarly, the per cent disease index (PDI) was recorded the highest in the cultivars Dohazari G and Laffa S. Less than $1 \%$ PDI was recorded for all the $\mathrm{F}_{4}$ lines of eggplant.

Table 1. Reaction of $\mathrm{F}_{4}$ lines and parents of eggplant against P. vexans in induced condition during 2006-2007 at Mymensingh, Bangldesh

\begin{tabular}{llllll}
\hline Phenotypes/ varieties & $\begin{array}{l}\text { Infected } \\
\text { leaves (\%) }\end{array}$ & $\begin{array}{l}\text { Per cent } \\
\text { disease } \\
\text { index (leaf) }\end{array}$ & $\begin{array}{l}\text { Infected } \\
\text { fruits (\%) }\end{array}$ & $\begin{array}{l}\text { Per cent } \\
\text { disease } \\
\text { index } \\
\text { (fruit) }\end{array}$ & $\begin{array}{l}\text { Disease } \\
\text { reaction }\end{array}$ \\
\hline \multicolumn{2}{l}{ (Dohazari G x BAU Begun-1) } & & & & \\
Green round & $2.97 \mathrm{c}$ & $0.42 \mathrm{c}$ & $1.42 \mathrm{bc}$ & $0.42 \mathrm{~b}$ & Resistant \\
Green globose & $3.12 \mathrm{c}$ & $0.43 \mathrm{c}$ & $1.83 \mathrm{~b}$ & $0.42 \mathrm{~b}$ & Resistant \\
Green long & $2.87 \mathrm{c}$ & $0.47 \mathrm{c}$ & $1.79 \mathrm{~b}$ & $0.39 \mathrm{~b}$ & Resistant \\
(Laffa Sx BAU Begun-1) & & & & & \\
Green globose & $2.86 \mathrm{c}$ & $0.38 \mathrm{c}$ & $1.37 \mathrm{bc}$ & $0.38 \mathrm{~b}$ & Resistant \\
Green white long & $2.83 \mathrm{c}$ & $0.45 \mathrm{c}$ & $1.38 \mathrm{bc}$ & $0.29 \mathrm{~b}$ & Resistant \\
Purple globose & $3.12 \mathrm{c}$ & $0.41 \mathrm{c}$ & $1.61 \mathrm{~b}$ & $0.30 \mathrm{~b}$ & Resistant \\
Purple long & $3.16 \mathrm{c}$ & $0.39 \mathrm{c}$ & $1.42 \mathrm{bc}$ & $0.44 \mathrm{~b}$ & Resistant \\
BAU Begun-1 & $0.00 \mathrm{~d}$ & $0.00 \mathrm{~d}$ & $0.00 \mathrm{c}$ & $0.00 \mathrm{~b}$ & Resistant \\
Dohazari G & $32.47 \mathrm{a}$ & $33.86 \mathrm{a}$ & $27.22 \mathrm{a}$ & $30.68 \mathrm{a}$ & Susceptible \\
Laffa S & $30.56 \mathrm{~b}$ & $30.57 \mathrm{~b}$ & $28.04 \mathrm{a}$ & $31.19 \mathrm{a}$ & Susceptible \\
\hline
\end{tabular}

Means followed by the same letter in a column did not differ significantly at the $1 \%$ level by DMRT 
The fruit infection of the tested phenotypes ranged from 0.00 to $28.04 \%$. The highest percentage of fruit infection was recorded in parent cultivar Laffa S followed by Dohazari G (Table 1). There was no fruit infection observed in the cultivar BAU Begun-1. All the $F_{4}$ lines of eggplants (Laffa $\mathrm{S} \times$ BAU Begun- 1 ) and (Dohazari $\mathrm{G} \times \mathrm{BAU}$ Begun-1) produced fruit infection less than $2 \%$ that were statistically similar. The per cent disease index was also the highest in Laffa S (31.19) followed by Dohazari G (30.68). However, all the $\mathrm{F}_{4}$ lines had less than $1 \%$ PDI, whereas BAU Begun-1 was found free from disease. $F_{1}$ and $\mathrm{F}_{2}$ offspring derived from two crosses, Laffa $\mathrm{S} x$ BAU Begun-1 and Dohazari G x BAU Begun-1 were reported free from diseases and graded as resistant to $\mathrm{P}$. vexans (Meah, 2007). In $\mathrm{F}_{3}$ populations, Kabir (2007) also reported similar results.

The tested phenotype were categorized according to Islam et al. (1990) and found parent cultivars Dohazari G and Laffa as susceptible to Phomopsis vexans and cultivar BAU Begun-1 was resistant. All the $F_{4}$ plants were grouped based on colour and shape and graded as resistant though a few plants showed infection (PDI less than 1\%). Fruit shape and colour had no effect on the intensity of infection (Table 1). Meah (2007) also reported that Laffa S and Dohazari G were susceptible and BAU Begun-1 (previously known as IPM-31) as resistant.

Table 2. Yield attributing characters of $F_{4}$ lines and their parents of eggplant affected due to Phomopsis blight and fruit rot in induced condition in 2006-2007 at Mymensingh

\begin{tabular}{|c|c|c|c|c|c|c|c|}
\hline $\begin{array}{l}\text { Phenotypes/ } \\
\text { varieties }\end{array}$ & $\begin{array}{l}\text { Plant } \\
\text { height (cm) }\end{array}$ & $\begin{array}{l}\text { Primary } \\
\text { branch } \\
\text { plant }^{-1}\end{array}$ & $\begin{array}{l}\text { Secondary } \\
\text { branch } \\
\text { plant }-1\end{array}$ & $\begin{array}{l}\text { Fruits } \\
\text { plant-1 }\end{array}$ & $\begin{array}{l}\text { Fruit } \\
\text { length } \\
\text { (cm) }\end{array}$ & $\begin{array}{l}\text { Fruit } \\
\text { width } \\
\text { (cm) }\end{array}$ & $\begin{array}{l}\text { Individual } \\
\text { fruit } \\
\text { weight (g) }\end{array}$ \\
\hline \multicolumn{8}{|c|}{ Dohazari G x BAU Begun-1 } \\
\hline Green round & $58.16 \mathrm{e}$ & $12.27 \mathrm{de}$ & $11.30 \mathrm{e}$ & $10.52 \mathrm{~d}$ & $11.42 \mathrm{~d}$ & $8.20 \mathrm{~b}$ & $246.0 \mathrm{e}$ \\
\hline Green globose & $62.24 \mathrm{~cd}$ & $11.68 \mathrm{e}$ & $12.10 \mathrm{de}$ & $12.80 \mathrm{~d}$ & $12.62 \mathrm{c}$ & $6.91 \mathrm{ef}$ & $259.9 d$ \\
\hline Green long & $59.97 \mathrm{de}$ & $13.18 \mathrm{bcd}$ & $13.08 \mathrm{~d}$ & $13.51 \mathrm{~d}$ & $15.59 \mathrm{ab}$ & 7.45 cde & 280.1 bc \\
\hline \multicolumn{8}{|c|}{ Laffa Sx BAU Begun-1 } \\
\hline Green globose & $60.85 \mathrm{de}$ & $14.58 \mathrm{a}$ & $13.18 \mathrm{~d}$ & $12.49 \mathrm{~d}$ & $12.13 \mathrm{~cd}$ & $8.09 \mathrm{~b}$ & $275.0 \mathrm{bc}$ \\
\hline Green whitelong & $59.04 \mathrm{de}$ & 12.58 cde & $15.12 \mathrm{c}$ & $13.32 \mathrm{~d}$ & $16.11 \mathrm{a}$ & $7.11 \mathrm{def}$ & $284.8 \mathrm{ab}$ \\
\hline Purple globose & $61.83 \mathrm{de}$ & $11.93 \mathrm{e}$ & $11.70 \mathrm{e}$ & $12.85 \mathrm{~d}$ & $11.78 \mathrm{~cd}$ & $7.79 \mathrm{bc}$ & $277.8 \mathrm{bc}$ \\
\hline Purplelong & $60.93 \mathrm{de}$ & $11.77 \mathrm{e}$ & $12.48 \mathrm{de}$ & $12.58 \mathrm{~d}$ & $15.80 \mathrm{ab}$ & $6.64 \mathrm{f}$ & $266.4 \mathrm{~cd}$ \\
\hline BAU Begun-1 & $65.45 \mathrm{bc}$ & $13.80 \mathrm{ab}$ & $17.76 \mathrm{a}$ & $17.81 \mathrm{~b}$ & $11.88 \mathrm{~cd}$ & $9.43 \mathrm{a}$ & $297.8 \mathrm{a}$ \\
\hline Dohazari G & $67.82 \mathrm{ab}$ & $11.81 \mathrm{e}$ & $16.38 \mathrm{~b}$ & $20.77 a$ & $14.97 \mathrm{~b}$ & $9.12 \mathrm{a}$ & $272.4 \mathrm{bcd}$ \\
\hline Laffa S & $70.43 \mathrm{a}$ & $13.49 \mathrm{bc}$ & $16.39 \mathrm{~b}$ & $21.13 \mathrm{a}$ & $15.23 \mathrm{ab}$ & $7.59 \mathrm{bcd}$ & $283.4 \mathrm{~b}$ \\
\hline
\end{tabular}

Means followed by the same letter in a column did not differ significantly at the $1 \%$ level by DMRT
All the yield contributing characters had significant differences amongst the phenotypes (Table 2). This means differences exist between the tested phenotypes even within the same environment where they were grown. Plant height ranged from 58.16 to $70.43 \mathrm{~cm}$. Laffa S was the tallest cultivars among the tested phenotypes which was statistically identical with Dohazari G (Table 2). In contrast, green round line of Dohazari G x BAU Begun-1 was the shortest.

Number of primary branches per plant ranged from 11.68 to 14.58. Green globose of Laffa S x BAU Begun- 1 cross produced maximum number of primary branches. Green globose of Dohazari G x BAU Begun-1 cross produced the lowest number of primary branches and it was statistically similar with most of the phenotypes. The highest number (14.76) of secondary branches was recorded in BAU Begun-1 and it was statistically different from all other phenotypes. The lowest number of secondary branches (11.30) was found in green round line (Dohazari G x BAU Begun-1). Number of fruits per plant ranged from 10.52 to 21.13 . The parent Laffa S produced the highest number of fruits. All the $\mathrm{F}_{4}$ phenotypes produced statistically similar number of fruits per plant.

\section{Performance of the phenotypes}


Fruit length varied from 11.42 to $16.11 \mathrm{~cm}$. The highest fruit length was recorded in green white long of $\mathrm{F}_{4}$ lines (Laffa $\mathrm{S} \times \mathrm{BAU}$ Begun-1). In contrast, the lowest fruit length was observed in the green round of $F_{4}$ lines (Dohazari $G \times$ BAU Begun-1). Fruit width was recorded as 6.64 to $9.43 \mathrm{~cm}$. The highest fruit width was observed in BAU Begun-1 followed by Dohazari G and both were statistically similar. The lowest fruit diameter was found in purple long (Laffa S x BAU Begun-1). Individual fruit weight ranged from 246.03 to $297.83 \mathrm{gram}$. The highest fruit weight was recorded in BAU Begun-1 (Figure 5) and the lowest in green round of $F_{4}$ lines (Dohazari $G x$ BAU Begun-1).

The significant differences were observed in all the characters studied amongst the phenotypes. Significant difference in plant height, number of branches per plant, number of fruits per plant, fruit length, fruit width and individual fruit weight have also been reported in different eggplant varieties (Islam and Uddin, 2009; Sharmin et al., 2010; Roychowdhury et al., 2011).

Variability, heritability and genetic advance for yield contributing characters
The highest genotypic variance $\left(\delta^{2} g\right)$ and phenotypic variance $\left(\delta^{2} p\right)$ was found in individual fruit weight (195.06 and 243.00) followed by plant height (15.11 and 18.05), number of fruits per plant (13.75 and 14.35). Low magnitude of $\delta^{2} \mathrm{~g}$ and $\delta^{2} \mathrm{p}$ were observed in number of secondary branches per plant, fruit length, number of primary branches per plant and fruit width (Table 3).

The genotypic coefficient of variation (GCV) and phenotypic coefficient of variation (PCV) ranged from 5.09 to 25.09 and 5.68 to 25.63, respectively. The highest genotypic coefficient of variation and phenotypic coefficient of variation was found in number of fruits per plant followed by number of secondary branch per plant. In contrast, the lowest GCV and PCV were calculated for individual fruit weight. Islam and Uddin (2009); Sharmin et al. (2010); Roychowdhury et al. (2011) also reported higher phenotypic coefficients of variation than genotypic ones for the yield contributing characters. High GCV indicated high genetic variability and thus results the scope for improvements of the characters.

Table 3. Estimation of genetic parameters for yield contributing characters in seven $F_{4}$ lines of eggplant and their parents

\begin{tabular}{|c|c|c|c|c|c|c|c|c|}
\hline Characters & Mean range & $\begin{array}{l}\text { Genotypic } \\
\text { variance } \\
\left(\sigma^{2} g\right)\end{array}$ & $\begin{array}{l}\text { Phenotypic } \\
\text { variance } \\
\left(\sigma^{2} p\right)\end{array}$ & $\begin{array}{c}\text { Genotypic } \\
\text { coefficient } \\
\text { of } \\
\text { variation } \\
(\%) \\
\end{array}$ & $\begin{array}{l}\text { Phenotypic } \\
\text { coefficient of } \\
\text { variation } \\
\text { (\%) }\end{array}$ & $\begin{array}{c}\text { Heritability } \\
\text { (\%) }\end{array}$ & $\begin{array}{l}\text { Genetic } \\
\text { advance }\end{array}$ & $\begin{array}{c}\text { Genetic } \\
\text { advance } \\
\text { (\%) }\end{array}$ \\
\hline $\begin{array}{l}\text { Plant height } \\
\text { (cm) }\end{array}$ & 58.16-70.43 & 15.11 & 18.05 & 6.20 & 6.78 & 83.71 & 7.33 & 11.69 \\
\hline $\begin{array}{l}\text { Number of } \\
\text { primary } \\
\text { branches plant }{ }^{1}\end{array}$ & $11.68-14.58$ & 0.94 & 1.22 & 7.63 & 8.69 & 77.05 & 1.75 & 13.79 \\
\hline $\begin{array}{l}\text { Number of } \\
\text { secondary } \\
\text { branches plant }{ }^{-1}\end{array}$ & $11.30-17.76$ & 5.11 & 5.44 & 16.20 & 16.72 & 93.93 & 4.51 & 32.35 \\
\hline $\begin{array}{l}\text { Number of fruits } \\
\text { plant }^{-1}\end{array}$ & $10.52-21.13$ & 13.75 & 14.35 & 25.09 & 25.63 & 95.82 & 7.48 & 50.59 \\
\hline $\begin{array}{l}\text { Fruit length } \\
\text { (cm) }\end{array}$ & $11.42-16.11$ & 3.67 & 3.91 & 13.93 & 14.38 & 93.86 & 3.82 & 27.81 \\
\hline Fruit width $(\mathrm{cm})$ & $6.64-9.43$ & 0.80 & 0.89 & 11.42 & 12.05 & 89.89 & 1.75 & 22.31 \\
\hline $\begin{array}{l}\text { Individual fruit } \\
\text { weight (g) }\end{array}$ & $\begin{array}{l}246.03- \\
297.83\end{array}$ & 195.06 & 243.00 & 5.09 & 5.68 & 80.27 & 25.78 & 9.40 \\
\hline
\end{tabular}

Heritability of the phenotypes ranged from 77.05 to $95.82 \%$. Almost all the characters showed more than $80 \%$ heritability. The highest heritability was calculated for number of fruits per plant followed by number of secondary branches per plant (93.93) and fruit length (93.86). High heritability for most of the characters of different eggplants was also reported (Islam and Uddin, 2009, Sharmin et al., 2010; Roychowdhury et al., 2011). The genetic advance and per cent genetic advance varied from 1.75 to 25.78 and 9.40 to 50.59 , respectively. The highest genetic advance was recorded for individual fruit weight; whereas genetic advance in percentage was found in number of fruits per plant, which means there is possibility for improving the characters. Similar results were also reported by Islam and Uddin, (2009); Sharmin et al. (2010) and Roychowdhury et al. (2011). Sharmin et al. (2010) and Roychowdhury et al. (2011) showed high heritability for number of fruits per plant with high genetic advance as percentage of mean, which is in agreement with the present study. 


\section{Relationship between different yield contributing characters}

Different yield contributing characters and their relationships were studied through analysis of correlation coefficients between characters (Table $4)$.

Plant height was positively correlated with number of primary branches per plant, fruit length, fruit width and individual fruit weight. But the relationship of plant height was significant with number of secondary branch per plant and number of fruits per plant. Positive correlation between plant height and eggplant yield also reported by Muniappan et al. (2010).

The relationship of number of primary branches per plant with number of secondary branches per plant, number of fruits per plant, fruit width and individual fruit weight was positive. The negative significant correlation was observed for primary branches per plant with fruit length. The number of secondary branches per plant was positively related with other characters. Significant relationships were calculated with number of fruits per plant and individual fruit weight. Insignificant relationship was observed with fruit length and fruit width.

The number of fruits per plant had positive correlation with fruit length, fruit width and individual fruit weight. Fruit length had negative correlation with fruit width. There was positive insignificant correlation between fruit length with individual fruit weight. Number of fruits has positive correlation with fruit yield also reported by Muniappan et al. (2010). Individual fruit weight was positively correlated with plant height, number of primary branches per plant, number of secondary branches per plant, number of fruits per plant, but insignificant with fruit length and fruit width.

Table 4. Correlation coefficients between different yield contributing characters in eggplant cultivars and their $\mathrm{F}_{4}$ lines

\begin{tabular}{|c|c|c|c|c|c|c|c|}
\hline Characters & $\begin{array}{l}\text { Plant } \\
\text { height } \\
\text { (cm) }\end{array}$ & $\begin{array}{l}\text { No. of } \\
\text { primary } \\
\text { branches } \\
\text { plant }^{-1}\end{array}$ & $\begin{array}{l}\text { No. of } \\
\text { secondary } \\
\text { branches } \\
\text { plant-1 }\end{array}$ & $\begin{array}{l}\text { No. of } \\
\text { fruits } \\
\text { plant }{ }^{-1}\end{array}$ & $\begin{array}{l}\text { Fruit } \\
\text { length } \\
\text { (cm) }\end{array}$ & $\begin{array}{l}\text { Fruit } \\
\text { width } \\
\text { (cm) }\end{array}$ & $\begin{array}{l}\text { Individual } \\
\text { fruit } \\
\text { weight } \\
\text { (g) }\end{array}$ \\
\hline Plant height (cm) & & 0.140 & $0.720^{* *}$ & $0.951^{* * *}$ & 0.159 & 0.407 & 0.418 \\
\hline $\begin{array}{l}\text { No. of primary branches } \\
\text { plant }^{-1}\end{array}$ & & & 0.392 & 0.170 & -0.154 & 0.336 & 0.531 \\
\hline $\begin{array}{l}\text { No. of secondary } \\
\text { branches plant }{ }^{-1}\end{array}$ & & & & $0.854^{* * *}$ & 0.291 & 0.564 & $0.742^{* *}$ \\
\hline Number of fruits plant ${ }^{-1}$ & & & & & 0.315 & 0.491 & 0.524 \\
\hline Fruit length $(\mathrm{cm})$ & & & & & & -0.430 & 0.240 \\
\hline $\begin{array}{l}\text { Fruit width (cm) } \\
\text { Individual fruit weight (g) }\end{array}$ & & & & & & & 0.304 \\
\hline
\end{tabular}

$*$, ** and *** indicate significant at 5\%, $1 \%$ and $0.1 \%$ level of probability, respectively.

Molecular characterization of $F_{4}$ lines of eggplants through RAPD markers

\section{RAPD profiles and analysis}

The genome DNA from three eggplant cultivars and their $\mathrm{F}_{4}$ lines when amplified with five different RAPD primers, various banding patterns were observed. Among the RAPD profiles, only two are presented in Photograph 1 and 2. The number of band ranged from 4 to 10 . The primer 67AB10G7, OPB10 and OPC05 produced the highest numbers of bands as well as polymorphic bands whereas the other two primers (OPA03 and OPB09) produced the lowest number of bands. So first three primers showed a higher level of polymorphism (Table 5). The band size ranged from 100 to $800 \mathrm{bp}$. RAPD analysis of BAU Begun-1, Laffa S, Dohazari G and their $\mathrm{F}_{4}$ lines revealed that the selected five primers generated 37 bands of which 26 (69.0\%) were polymorphic and 11 (31.0\%) were monomorphic. 
Table 5. RAPD primers with corresponding bands scored and their size range together with polymorphic bands observed in three parents (Dohazari G, Laffa S and BAU Begun-1) and their seven $\mathrm{F}_{4}$ lines of eggplant

\begin{tabular}{|c|c|c|c|c|c|}
\hline Primer code & $\begin{array}{l}\text { Primer } \\
\left(5^{\prime}-3^{\prime}\right)\end{array}$ & Band size (bp) & $\begin{array}{l}\text { Total bands } \\
\text { scored }\end{array}$ & $\begin{array}{l}\text { Polymorphic } \\
\text { bands }\end{array}$ & $\begin{array}{l}\text { Polymorphic } \\
\text { loci (\%) }\end{array}$ \\
\hline 67AB10G7 & TTG GCA CGG G & $100-600$ & 10 & 8 & 80.00 \\
\hline OPA03 & AGT CAG CCA C & $100-300$ & 4 & 3 & 75.00 \\
\hline OPB09 & TGG GGG ACT C & $140-300$ & 5 & 3 & 60.00 \\
\hline OPB10 & CTG CTG GGA C & $160-800$ & 10 & 8 & 80.00 \\
\hline OPC05 & GAT GAC CGC C & $110-500$ & 8 & 4 & 50.00 \\
\hline Total & & & 37 & 26 & 345.00 \\
\hline Average & & & 7.4 & 5.2 & 69.00 \\
\hline
\end{tabular}

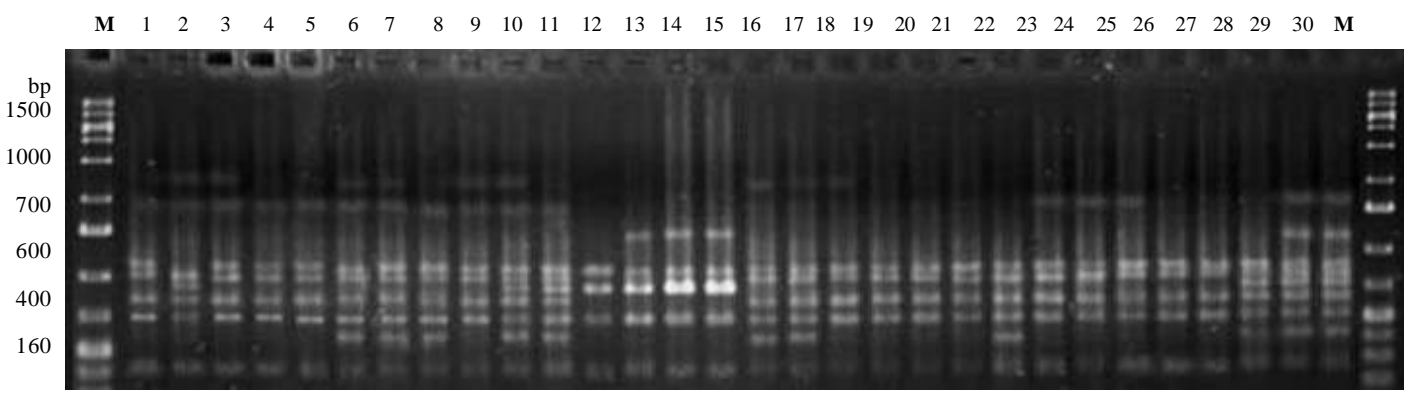

Photograph 1. RAPD profiles of 3 parents and their $7 \mathrm{~F}_{4}$ progenies using primer OPB10 (M: 20bp ladder, Lane 1-3: BAU Begun-1, Lane 4-6: Dohazari G, Lane 7-9: Laffa S, Lane 10-12: Green round (Dohazari G x BAU Begun-1), Lane 13-15: Green globose (Dohazari G x BAU Begun-1), Lane 16-18: Green long (Dohazari G x BAU Begun-1), Lane 19-21: Green globose (Laffa S x BAU Begun-1), Lane 22-24: Green white long (Laffa S x BAU Begun-1), Lane 25-27: Purple globose (Laffa S x BAU Begun1) and Lane 28-30: Purple long (Laffa Sx BAU Begun-1).

$\begin{array}{lllllllllllllllllllllllllllllllll}\text { M } & 1 & 2 & 3 & 4 & 5 & 6 & 7 & 8 & 9 & 10 & 11 & 12 & 13 & 14 & 15 & 16 & 17 & 18 & 19 & 20 & 21 & 22 & 23 & 24 & 25 & 26 & 27 & 28 & 29 & 30 & \text { M }\end{array}$

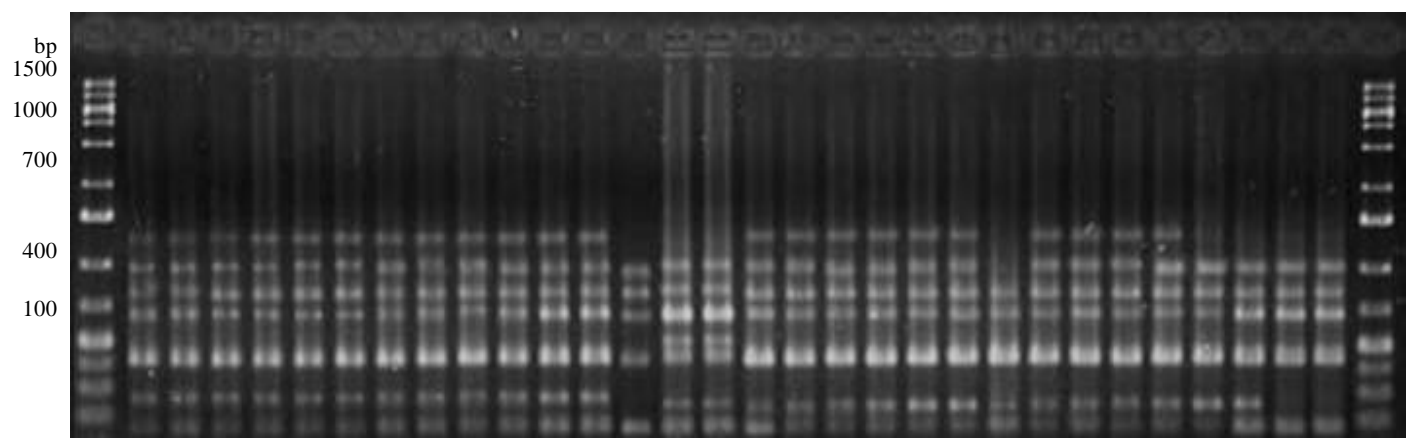

Photograph 2. RAPD profiles of 3 parents and their $7 \mathrm{~F}_{4}$ progenies using primer OPC05 (M: 20bp ladder, Lane 1-3: BAU Begun-1, Lane 4-6: Dohazari G, Lane 7-9: Laffa S, Lane 10-12: Green round (Dohazari G x BAU Begun-1), Lane 13-15: Green globose (Dohazari G x BAU Begun-1), Lane 16-18: Green long (Dohazari G x BAU Begun-1), Lane 19-21: Green globose (Laffa S x BAU Begun-1), Lane 22-24: Green white long (Laffa S x BAU Begun-1), Lane 25-27: Purple globose (Laffa S x BAU Begun1) and Lane 28-30: Purple long (Laffa Sx BAU Begun-1). 
The number of band and polymorphic band per primer obtained 7.4 and 5.2, respectively (Table 5). The number of polymorphic band per primer have been reported 4.0, 5.3 and 5.9 in eggplant by Laila et al. (2012), Sharmin et al. (2011) and Karihaloo et al. (1995), respectively. The difference might be due to the use of different primers and eggplant varieties. The percentage of polymorphic loci was 69.00 for Laffa S, Dohazari G, BAU Begun- 1 and their $\mathrm{F}_{4}$ lines. Similar level of polymorphism expressed by arbitrary primers in eggplant also available (Laila et al., 2012; Sharmin et al., 2011).

\section{Frequency of polymorphic loci}

The number and proportion of polymorphic loci was found to be the highest in green white long line of Laffa S x BAU Begun-1 (27.03\%) and the lowest on green long $\left(\mathrm{F}_{4}\right.$ line of Dohazari $\mathrm{G} \times$ BAU Begun-1) and green globose $\left(\mathrm{F}_{4}\right.$ line of Laffa $S \times$ BAU Begun-1) (Table 6). The highest proportion of Nei's gene diversity value and Shannon's Information index were found in green white long $\left(\mathrm{F}_{4}\right.$ line of Laffa $\mathrm{S} x$ BAU Begun1) which was 0.1166 and 0.1675 , respectively. On the other hand, the lowest proportion of polymorphic loci and Nei's gene diversity value were found in purple globose $\left(\mathrm{F}_{4}\right.$ line of Laffa $\mathrm{S} \times$ IPM-31) (Table 6).

Table 6. Estimates of genetic variation, number and proportion of Polymorphic loci, gene diversity and Shannon's Information index obtained in 3 cultivars and $7 \mathrm{~F}_{4}$ lines of eggplant

\begin{tabular}{lllll}
\hline Phenotypes/ varieties & $\begin{array}{l}\text { No. of } \\
\text { polymorphic loci }\end{array}$ & $\begin{array}{l}\text { Proportion of } \\
\text { polymorphic loci } \\
(\%)\end{array}$ & $\begin{array}{l}\text { Gene } \\
\text { diversity } \\
\text { (h) }\end{array}$ & $\begin{array}{l}\text { Shannon's } \\
\text { Information index } \\
\text { (I) }\end{array}$ \\
\hline BAU Begun-1 & 7 & 18.92 & 0.0720 & 0.1068 \\
Laffa S & 6 & 16.22 & 0.0639 & 0.0939 \\
Dohazari G & 5 & 13.51 & 0.0558 & 0.0810 \\
Green round (D)* & 8 & 21.62 & 0.1004 & 0.1417 \\
Green globose(D) & 4 & 10.81 & 0.0477 & 0.0681 \\
Green long(D) & 1 & 2.70 & 0.0132 & 0.0184 \\
Green globose(L)** & 1 & 2.70 & 0.0132 & 0.0184 \\
Green whitelong(L) & 10 & 27.03 & 0.1166 & 0.1675 \\
Purple globose (L) & 3 & 8.11 & 0.0294 & 0.0442 \\
Purple long(L) & 4 & 10.81 & 0.0426 & 0.0626 \\
\hline
\end{tabular}

*Green round (D) = Green round progeny of Dohazari G x BAU Begun-1

$* *$ Green globose $(\mathrm{L})=$ Green globose progeny of Laffa S x BAU Begun-1

The DNA polymorphisms are detected by band presence versus absence and may be caused by failure to prime a site in some individuals due to nucleotide sequence difference or by insertions or deletions between priming sites (Clark and Langigan, 1993).

\section{Genetic identity and genetic distance}

Genetic identity between varieties was found for the 5 primers, ranged from 0.5661 to 0.9883 (Table 7). Comparatively the higher genetic identity was found in green globose (Laffa S x BAU Begun-1) vs. purple globose (Laffa S x BAU Begun-1) followed by purple globose (Laffa $S \mathrm{x}$ BAU Begun-1) vs. green white long (Laffa S x BAU Begun-1). The lowest genetic identity was observed between green globose (Laffa S x BAU Begun-1) vs. Laffa S.
The values of pair-wise comparisons of Nei's (1972) genetic distance between varieties were computed from combined data for the 5 primers, ranged from 0.0177 to 0.5689 (Table 7). Comparatively, higher genetic distance was observed between Laffa S vs. green globose (Dohazari G x BAU Begun-1), BAU Begun-1 vs. green globose (Dohazari G x BAU Begun-1) and Dohazari G vs. green globose (Dohazari G x BAU Begun-1) phenotype pairs than other phenotype combinations. The lowest genetic distance was found in green globose (Laffa S x BAU Begun-1) vs. purple globose (Laffa S x BAU Begun-1) phenotype pair. Considering the genetic distance values, the varieties were genetically different from each other. 
Table 7. Summary of Nei's (1972) genetic identity (above diagonal) and genetic distance (below diagonal) values for ten phenotype pairs of eggplant

\begin{tabular}{lcccccccccc}
\hline $\begin{array}{l}\text { Phenotypes/ } \\
\text { varieties }\end{array}$ & $\begin{array}{c}\text { BAU } \\
\text { Begun-1 }\end{array}$ & LaffaS & Dohazari G & $\begin{array}{c}\text { Green } \\
\text { round (D) }\end{array}$ & $\begin{array}{c}\text { Green } \\
\text { globose(D) }\end{array}$ & $\begin{array}{c}\text { Green } \\
\text { long (D) }\end{array}$ & $\begin{array}{c}\text { Green } \\
\text { globose(L) }\end{array}$ & $\begin{array}{c}\text { Green } \\
\text { whitelong } \\
\text { (L) }\end{array}$ & $\begin{array}{c}\text { Purple } \\
\text { globose (L) }\end{array}$ & $\begin{array}{c}\text { Purple } \\
\text { long }\end{array}$ \\
\hline BAU Begun-1 & $* * * *$ & 0.9148 & 0.9326 & 0.8616 & 0.6029 & 0.8608 & 0.8934 & 0.8943 & 0.8964 & 0.7665 \\
Laffa S & 0.0891 & $* * * *$ & 0.9322 & 0.8404 & 0.5661 & 0.8147 & 0.8562 & 0.8626 & 0.8590 & 0.7025 \\
Dohazari G & 0.0698 & 0.0703 & $* * * *$ & 0.8663 & 0.6262 & 0.8500 & 0.8723 & 0.8593 & 0.8752 & 0.7435 \\
Green round (D) & 0.1490 & 0.1738 & 0.1435 & $* * * *$ & 0.7770 & 0.8563 & 0.8929 & 0.8674 & 0.8897 & 0.8525 \\
Green globose (D) & 0.5060 & 0.5689 & 0.4681 & 0.2523 & $* * * *$ & 0.6507 & 0.7005 & 0.6760 & 0.7217 & 0.7379 \\
Green long (D) & 0.1499 & 0.2050 & 0.1626 & 0.1552 & 0.4298 & $* * * *$ & 0.9586 & 0.8904 & 0.9389 & 0.8326 \\
Green globose (L) & 0.1127 & 0.1552 & 0.1366 & 0.1133 & 0.3559 & 0.0423 & $* * * *$ & 0.9438 & 0.9883 & 0.8326 \\
Green whitelong (L & 0.1117 & 0.1478 & 0.1516 & 0.1422 & 0.3915 & 0.1161 & 0.0578 & $* * *$ & 0.9604 & 0.8445 \\
Purple globose (L) & 0.1094 & 0.1520 & 0.1333 & 0.1169 & 0.3262 & 0.0630 & 0.0117 & 0.0404 & $* * * *$ & 0.8482 \\
Purplelong (L) & 0.2659 & 0.3532 & 0.2964 & 0.1596 & 0.3039 & 0.1832 & 0.1832 & 0.1690 & 0.1646 & $* * * *$ \\
\hline
\end{tabular}

*Green round $(\mathrm{D})$ = Green round progeny of Dohazari Gx BAU Begun-1

**Green globose $(\mathrm{L})=$ Green globose progeny of Laffa S x BAU Begun-1

\section{Dendrogram of $\mathrm{F}_{4}$ lines and their parents}

Dendrogram based on Nei's (1972) genetic distance using Unweighted Pair Group Method of Arithmetic Means (UPGMA) indicated segregation of the phenotypes of eggplant into two main clusters: nine phenotypes grouped into cluster I and only green globose $\left(\mathrm{F}_{4}\right.$ line of Dohazari G x BAU Begun-1) grouped in cluster 2 (Fig. 1).

In cluster 1, BAU Begun-1, Dohazari G, Laffa S, green round and green long $\left(\mathrm{F}_{4}\right.$ line of Dohazari $\mathrm{G}$ $\mathrm{x}$ BAU Begun-1), green globose, purple globose and green white long ( $F_{4}$ lines of Laffa $\mathrm{S} x$ BAU Begun-1) formed sub cluster 1 while purple long ( $\mathrm{F}_{4}$ line of Laffa $\mathrm{S} x$ BAU Begun-1) was in sub cluster 2 . Among the phenotypes of sub cluster 1 , the three parent cultivars BAU Begun-1, Dohazari $\mathrm{G}$ and Laffa $\mathrm{S}$ formed sub sub cluster 1 and $\mathrm{F}_{4}$ lines of eggplant belonged to sub sub cluster 2 .
$\mathrm{F}_{4}$ lines of the tested phenotypes showed similar disease reaction and also produced similar number of fruits and formed same sub cluster. The parent cultivars are produce similar number of fruits, but they are different in case of disease reaction and finally divided into two groups, susceptible cultivars Laffa S and Dohazari G belonged to group 1 and the resistant parent BAU Begun-1 formed another group. On the other hand sub sub cluster 2 were divided into two groups, green round of Dohazari G x BAU Begun-1 formed sub group 1 and other four phenotypes were in sub group 2.

Eggplant germplasms of the Indian subcontinent are very diverse. Wide variation in the desirable phenotypes in different regions substantiates the high level of genetic variability (Karihaloo et al., 1995). Thus, the present study showed different types of reaction and grouping.

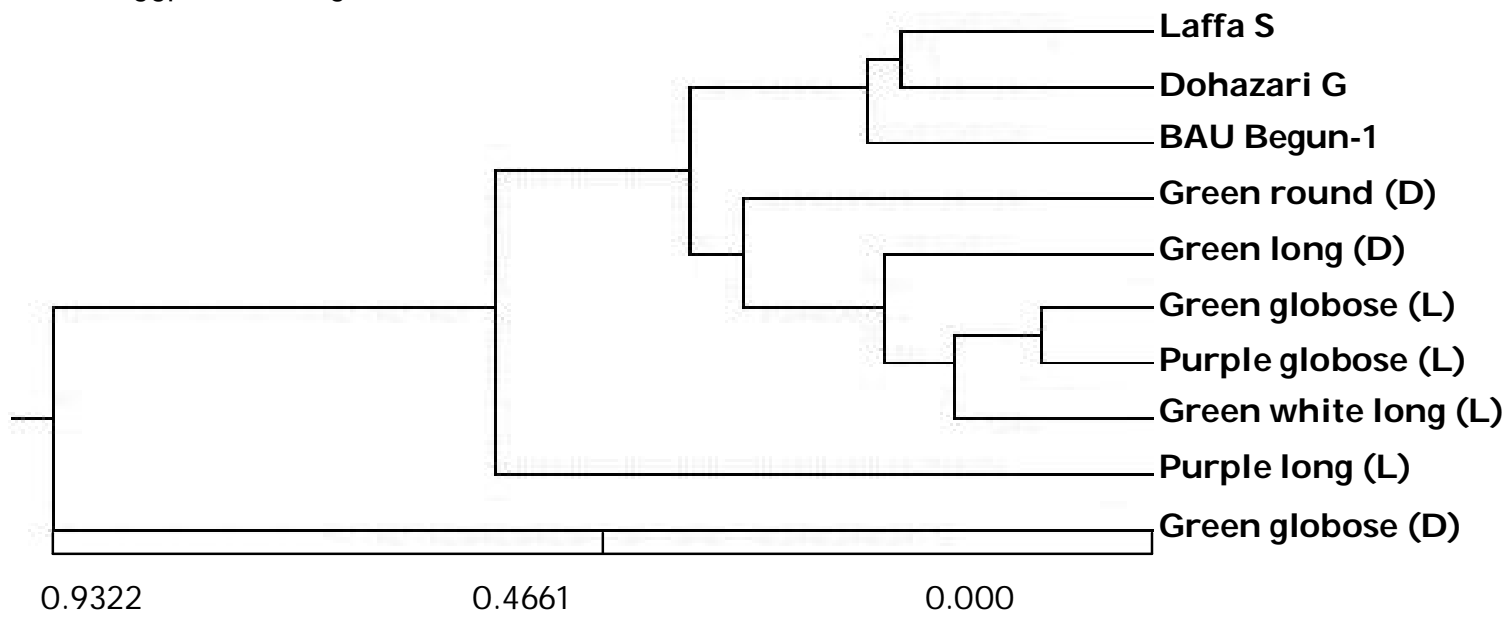

Fig. 1. UPGMA dendrogram based on Nei's (1972) genetic distance summarizing the data on differentiation between 3 cultivars and $7 \mathrm{~F}_{4}$ lines of eggplant, according to RAPD analysis [Green round $(\mathrm{D})=$ Green round progeny of Dohazari $\mathrm{G}$ x BAU Begun- 1 , Green globose $(\mathrm{L})=$ Green globose progeny of Laffa Sx BAU Begun-1]. 
Among the three parent and their $7 \mathrm{~F}_{4}$ lines studied, the cultivar BAU Begun- 1 and $F_{4}$ lines showed resistant reaction and rest parents showed susceptible reaction to phomopsis blight and fruit rot. According the RAPD analysis, three cultivars and $6 \mathrm{~F}_{4}$ lines grouped in same cluster and finally resistant parent formed separate sub sub cluster. Therefore, the result of the present study indicates that the variability and diversity present among the phenotypes, which will be useful for development of new eggplant cultivars.

\section{References}

Allard, R.W. 1960. Principles of Plant Breeding. John Willey and Sons. Inc. New York. p. 36.

Anonymous. 2005. Fertilizer Recommendation Guide, Bangladesh Agricultural Research Council, Farmgate, Dhaka. p. 108.

Baswana, K.S., Bhatia, M.K., Dharamveer, D. and Duhan, D. 2002. Genetic variability and heritabilty studies in rainy season brinjal (Solanum melongena L.). Harayana J. Hort. Sci. 31: 143-145.

BBS (Bangladesh Bureau of Statistics). 2011. Statistical Yearbook of Bangladesh. Bangladesh Bureau of Statistics. Ministry of Planning, Government of the Peoples' Republic of Bangladesh. $139 \mathrm{p}$.

Bidochka, M.J., McDonald, M.A., Leger R.J. and Roberts. D.W. 1994. Differentiation of species and strains of entomopathogenic fungi by random amplification of polymorphic DNA (RAPD). Current Genet. 25: 107- 113.

Burton, G.M. 1952. Quantitative inheritance in grasses. Proceedings of $6^{\text {th }}$ International Grassland Congress. pp. 277-283.

Chen, N.C., Kalb, T., Talekar, N.S., Wang, J.F. and Ma, C.H. 2002. AVRDC Training Guide: Suggested Cultural Practices for Eggplant. p. 4.

Choudhary, B. and Gaur, K. 2009. The development and regulation of Bt brinjal in India (Eggplant/Aubergine). International Service for the Acquisition of Agri-biotech Applications (ISAAA) Brief No. 38. ISAAA, Ithaca, NY, USA. $15 \mathrm{p}$.

Clark, A.G. and Langigan, C.M.S. 1993. Prospects for estimating nucleotide divergence with RAPDs. Mol. Evolution. 10: 1096-1111.

Comstock, R.E. and Robinson, H.F. 1952. Genetic parameters, their estimation and significance. Proc. $6^{\text {th }}$ International Congress. pp. 284-291.

Das, B.H. 1998. Studies on Phomopsis fruit rot of brinjal. M.S. thesis. Department of Plant Pathology, Bangladesh Agricultural University, Mymensingh. 64 p.
FAO. 2010. Food and Agriculture Organization (FAO)database.http:// www.faostat.fao.org/ site/ 567/ DesktopDefault.aspx.

Fukuan, Z., Gao, X.H., Cheng, G.H., Fran, S.X. and Ying, Y. 2003. RAPD analysis and identification of chilling resistance of cellular variant of the eggplant. Acta Agric. Boreali Sinica. 18: 17-19.

Islam, M.R. 2006. An integrated approach for management of Phomopsis blight and fruit rot of eggplant. Ph.D. thesis. Department of Plant Pathology, Bangladesh Agricultural University, Mymensingh. $133 \mathrm{p}$.

Islam, M.S. and Uddin, M.S. 2009. Genetic variation and trait relationship in the exotic and local eggplant germplasm. Bangladesh J. Agril. Res. 34 (1): 91-96.

Islam, S.K., Sintansu, P. and Pan, S. 1990. Efficacy of humidity and temperature on Phomopsis fruit rot of brinjal. Environ. Ecology. 8: 1309-1310.

Johnson, H.W., Robinson, H.F. and Comstock, R.E. 1955. Estimation of genetic and environmental variability in Soybean. Agron. J . 47: 314-318.

Kabir, M.M. 2007. Molecular characterization of $\mathrm{F}_{3}$ offspring of eggplant crosses for resistance to Phomosis blight and fruit rot. M.S. thesis. Department of Plant Pathology, Bangladesh Agricultural University, Mymensingh. $102 \mathrm{p}$.

Kalda, T.S., Swarup, V. and Choudhury, B. 1977. Resistance to Phomopsis blight in eggplant. Veg. Sci. 4: 90-101.

Karihaloo J.I., Brauner, S. and Gottlieb, L.D. 1995. Random amplified polymorphic DNA variation in the eggplant, Solanum melongena L (Solanaceae). Theor. Appl. Genet. 90: 767-770.

Laila, R., Siddiqua, M.K., Khalil, I., Robin, A.H.K. and Meah. B. 2012. Molecular characterization of Solanum melongena using RAPD marker for collar rot resistance. Int. Res. J . Appl. Life Sci. 1(4): 38-65.

Meah, M.B. 2007. Development of an integrated approach for management of Phomopsis blight and fruit rot of eggplant in Bangladesh. Final research report (20012006). Dept. of Plant Pathology, Bangladesh Agricultural University, Mymensingh, Bangladesh. pp. 67-75.

Meah, M.B., Ahmed, S.A., Islam, M.R., Islam, M.M. and Tusher, M.K. 2007. Eggplant of Bangladesh (2 ${ }^{\text {nd }}$ edition). IPM Laboratory, Department of Plant Pathology, Bangladesh Agricultural University, Mymensingh, Bangladesh. $27 \mathrm{p}$.

Meah, M.B., Hossain, M.D. and Islam, M.R. 2002. Development of an integrated approach for management of Phomopsis blight and fruit rot of eggplant in 
Bangladesh. Annual research report (20012002). Department of Plant Pathology, Bangladesh Agricultural University, Mymensingh, Bangladesh. pp. 8-10.

Miller, P.A., Williams, J.C., Robinson, H.F. and Comstock, R.E. 1958. Estimates of genetic and environmental variance and covariance and their implication in selection. Agron. J. 50: 126-131.

Muniappan, S., Saravanan, K. and Ramya, B. 2010. Studies on genetic divergence and variability for certain economic characters in eggplant (Solanum melongena L.). Electronic J. Plant Breed. 1(4): 462-465.

Nei, M. 1972. Genetic distance between populations. American Naturalist. 106: 283292.

Roychowdhury, R., Roy, S. and Tah, J. 2011. Estimation of heritable components of variation and character selection in eggplant (Solanum melongena L.) for mutation breeding programme. Continental J. Biol. Sci. 4 (2): 31-36.

Sharmin, D., Khalil, M.I., Begum, S.N. and Meah, M.B. 2011. Molecular characterization of eggplant crosses by using RAPD analysis. Int. J. Sust. Crop Prod. 6 (1): 22-28.
Sharmin, D., Meah, M.B. and Moniruzzaman, M. 2010. Inheritance of resistance to phomopsis blight and fruit rot in brinjal. J . Agroforestry Environ. 3 (2): 135-140.

Singh, N., Gyanendra, S. and Kalda, T.S. 1999. Genetic diversity in eggplant. IPGRINewsletter for Asia, the Pacific and Oceana. 29: 22.

Singh, P.K. and Chaudhary, B.D. 1985. Biometrical Methods in Quantitaive Genetic Analysis. Kalyani Publishers, New Delhi, India. $318 \mathrm{p}$.

Singh, R.S. 1984. An Introduction to Principles of Plant Pathology. 2nd edn. IBH Publishing Co. Delhi, India. 608 p.

Williams, J.G.K., Kubclik, A.R, Livak, K.J., Rafalski, J.A. and Tingey, S.V. 1990. DNA polymorphisms amplified by arbitrary primers are useful as genetic markers. Nucleic Acids Res. 18: 6531-6535.

Yeh, F.C., Yang, R.C., Boyle, T.B.J., Ye, Z.H. and Mao, J.X. 1999. POPGENE. The userfriendly software for population genetics analysis. Molecular Biology and Biotechnology Centre, university of Albetra, Canada. 29 p. 